\title{
LISTA WIERZYTELNOŚCI A UMORZENIE POSTĘPOWANIA SĄDOWEGO Glosa do UCHWAŁy SĄDU NAJWYŻSZEGo Z DNIA 18 STYCZNIA 2019 R., sYGN. AKT III CZP 55/18
}

\begin{abstract}
Uzyskanie przez powoda po wszczęciu postępowania tytułu egzekucyjnego w postaci wyciągu z zatwierdzonej przez sędziego komisarza listy wierzytelności skutkuje umorzeniem postępowania na podstawie art. 355 § 1 k.p.c.
\end{abstract}

\section{Wprowadzenie}

W postępowaniu upadłościowym wierzyciel uzyskuje tytuł egzekucyjny w postaci wyciągu z zatwierdzonej listy wierzytelności, który w przypadku braku zaspokojenia jego wierzytelności w postępowaniu egzekucyjnym, stanowi podstawę prowadzenia postępowania egzekucyjnego. Tytuł egzekucyjny powstaje jednak dopiero po zakończeniu postępowania upadłościowego. Wierzyciel (powód) może jednak wcześniej zainicjować postępowanie sądowe, w toku którego może dojść do ogłoszenia upadłości dłużnika (pozwanego). Prowadzenie jednocześnie postępowania upadłościowego i postępowania sądowego, którego celem jest uzyskanie tożsamego tytułu egzekucyjnego, nie znajduje uzasadnienia faktycznego. Wydaje się, że koniecznym jest znalezienie takiego rozwiązania prawnego, które hamowałoby możliwość prowadzenia dwóch postępowań, których efekt jest częściowo identyczny. Glosowane orzeczenie Sądu Najwyższego (SN) jest próbą znalezienia takiego właśnie rozwiązania prawnego. Czy jednak wskazane rozwiązanie prawne jest wystarczające?

* Dr, Katolicki Uniwersytet Lubelski Jana Pawła II; e-mail: pwrzaszcz@kul.pl, ORCID ID: https:/ / orcid.org/0000-0002-2062-9004. 


\section{Przedmiot glosy}

Uchwała Sądu Najwyższego z dnia 18 stycznia 2019 r. (sygn. akt III CZP 55/18) jest konsekwencją rozpoznania zagadnienia prawnego przedstawionego Sądowi Najwyższemu przez Sąd Apelacyjny w (...) postanowieniem z dnia 22 czerwca 2018 r., o następującej treści:

Czy uzyskanie przez powoda po wszczęciu postępowania cywilnego tytułu egzekucyjnego w postaci zatwierdzonej przez sędziego komisarza listy wierzytelności czyni zbędnym kontynuowanie postępowania cywilnego i wydanie wyroku, czy też jedynie świadczy o braku interesu prawnego w żądaniu udzielenia ochrony prawnej?.

\section{Stan faktyczny}

Glosowane orzeczenie zostało wydane w odniesieniu do następującego stanu fatycznego:

Sąd Okręgowy w W. wyrokiem z dnia 16 grudnia 2016 r. zasądził solidarnie od pozwanych K. sp. z o.o. w W. i Skarbu Państwa - Komisji Nadzoru Finansowego określone kwoty z tytułu umowy o roboty budowlane. Apelację od tego wyroku wnieśli obaj pozwani. $W$ toku postępowania apelacyjnego powód powołał się na fakt istnienia zatwierdzonej przez sędziego komisarza listy wierzytelności pozwanej spółki. W związku z tym Sąd Apelacyjny w [...] powziął poważne wątpliwości, którym dał wyraz w zagadnieniu prawnym przedstawionym do rozstrzygnięcia Sądowi Najwyższemu na podstawie art. 390 § 1 k.p.c. ${ }^{2}$

\section{Stanowisko Sądu Najwyższego}

Celem przedstawionego SN zagadnienia prawnego była próba znalezienia odpowiedzi na pytanie, czy uzyskanie przez wierzyciela tytułu

1 Uchwała Sądu Najwyższego z dnia 18 stycznia 2019 r., III CZP 55/18, http:/ / www. sn.pl/sites/orzecznictwo/orzeczenia3/iii\%20czp\%2055-18.pdf [dostęp: 23.04 .2019 r.].

2 Ustawa z dnia 17 listopada 1964 r. - Kodeks postępowania cywilnego, tekst jednolity: Dz. U. z 2019 r. poz. 1460 z późn. zm. (dalej: k.p.c.). 
egzekucyjnego w postępowaniu upadłościowym może skutkować umorzeniem postępowania sądowego, czy też oznacza brak interesu prawnego strony w jego uzyskaniu, czego konsekwencją powinno być oddalenie powództwa. Sąd apelacyjny chciał rozwikłać swoje wątpliwości co do treści rozstrzygnięcia, jakie winien na tym etapie postępowania wydać. Już na wstępie należy odnotować, że sąd, który przedstawił SN zagadnienie prawne wskazał, że to właśnie na etapie postępowania odwoławczego pozyskał informację o zatwierdzeniu listy wierzytelności w postępowaniu upadłościowym pozwanego, co wzbudziło jego wątpliwość w kontekście zasadności i celowości dalszego kontynuowania postępowania sądowego. Treść udzielonej przez SN odpowiedzi miała mieć zatem wpływ na zachowanie się sądu w prowadzonym procesie i ma kapitalne znaczenie dla przebiegu prowadzonych postępowań sądowych.

W przywołanej uchwale SN, dokonując interpretacji przepisów prawa procesowego, stanął na stanowisku, że wobec dezaktualizacji potrzeby udzielenia żądanej przez strony ochrony prawnej, na skutek uzyskania tytułu egzekucyjnego $\mathrm{w}$ innym postępowaniu (np. postępowaniu upadłościowym), wydanie orzeczenia kończącego postępowanie w sprawie o charakterze procesowym $\mathrm{w}$ postaci umorzenia procesu jest w pełni wystarczające dla uczynienia zadość prawu stron do sądu i rzetelnego procesu. Tym samym uznał, że nie ma racjonalnego uzasadnienia dla dalszego prowadzenia tego postępowania. Zajmując przywołane stanowisko SN wyjaśnił, że norma prawna zawarta w treści art. 355 § 1 k.p.c. w części, w jakiej odnosi się do zbędności wyrokowania - nie jest normą pustą. Rozumienie pojęcia "zbędności wydania wyroku” musi być powiązane $\mathrm{z}$ odpadnięciem $\mathrm{w}$ toku procesu interesu prawnego powoda $\mathrm{w}$ dochodzeniu roszczenia, a zatem $\mathrm{z}$ odpadnięciem materialnej przesłanki prowadzenia postępowania. Sąd Najwyższy wnioskował więc, że skoro $\mathrm{w}$ toku postępowania sądowego wygasł interes prawny strony, gdyż uzyskała ona ochronę prawną w inny sposób - poza postępowaniem sądowym (np. w toku postępowania upadłościowego) - to wówczas nie może ona oczekiwać, że prowadzone postępowanie doprowadzi ją do oczekiwanego rezultatu, którym byłoby uzyskanie korzystnego dla niej rozstrzygnięcia prawnego.

W ocenie SN dalsze prowadzenie postępowania w kierunku wydania wyroku oddalającego powództwo wydaje się być zbyteczne i bezcelowe, z czym nie trudno się nie zgodzić. Tym samym finalnym rozstrzygnięciem, jakie winno być wydane w tak zaistniałym stanie faktycznym, jest 
umorzenie postępowania na skutek braku celowości w jego kontynuowa$\mathrm{niu}^{3}$. Zajęte tym samym przez SN stanowisko, w istocie rzeczy, odpowiada potrzebom stron, jak również usprawiedliwia brak konieczności dalszego prowadzenia postępowania sądowego.

\section{Ocena stanowiska Sądu Najwyższego}

Oceniając treść rozstrzygnięcia SN, a w zasadzie próbując dokonać właściwej interpretacji zajętego stanowiska, nie trudno odmówić racji tak wyeksplikowanemu poglądowi. Niemniej jednak ocena winna być poprzedzona wskazaniem celu podjętej uchwały, a przede wszystkim konieczności uwypuklenia faktu, że jej treść ma istotne znaczenie dla dalszego procedowania przez sądy, a właściwie stwierdzenia, czy znajdą one usprawiedliwienie dla braku kontynuowania postępowania sądowego w sytuacji, gdy wierzyciel legitymuje się zatwierdzoną listą wierzytelności, na której została uznana jego wierzytelność. Mowa oczywiście o tej samej wierzytelności, która jest dochodzona w postępowaniu sądowym.

Sąd Najwyższy, podejmując uchwałę, winien mieć przede wszystkim na uwadze to, że jej treść ma mieć również wymiar praktyczny i oddziaływać w sposób bezpośredni na linię orzeczniczą sądów I i II instancji. Sądy bowiem staną przed realnym dylematem, czy w konkretnej sprawie zachodzi podstawa do umorzenia postępowania sądowego, a zatem czy zaistniały podstawy usprawiedliwiające działanie sądu, który odmawia dalszego kontynuowania postępowania. Uchwała SN winna więc w sposób konkretny oddziaływać na orzecznictwo sądów i prezentować im konkretne rozwiązania procesowe, które będzie można w sposób efektywny wykorzystać w postępowaniu sądowym.

Stanowisko zajęte przez SN w treści przywołanej uchwały, co do zasady jest właściwe, ale z punktu widzenia praktyki orzeczniczej - niepełne.

3 Zob. postanowienie Sądu Najwyższego z dnia 5 grudnia 1996 r., I PKN 34/96, OSNP 1997, nr 13, poz. 237; postanowienie Sądu Najwyższego z dnia 23 lutego 2001 r., II CKN 393/00, OSNC 2001, nr 11, poz. 162; postanowienie Sądu Najwyższego z dnia 2 lutego 2006 r., II CK 391/05, niepubl.; postanowienie Sądu Najwyższego z dnia 3 kwietnia 2008 r., II CSK 561/07, OSNC-ZD 2009, nr 2, poz. 38. 
Odnotować wypada przede wszystkim to, że dla sądu, prowadzącego postępowanie sądowe bez względu na to, czy nastąpi umorzenie tego postępowania, czy też oddalenie powództwa na skutek uzyskania tytułu egzekucyjnego w innym postępowaniu (tutaj - postępowaniu upadłościowym), oznacza, że postępowanie to uległo zakończeniu. Z punktu widzenia interesu strony, treść zapadłego rozstrzygnięcia nie ma też, co do zasady, większego znaczenia w sytuacji, gdy uzyskała ona tytuł egzekucyjny $\mathrm{w}$ innym postępowaniu. Jego wykonanie bowiem i tak nastąpi już nie na drodze postępowania rozpoznawczego, ale w wyniku przeprowadzonego postępowania egzekucyjnego, jeżeli zaspokojenia swoich wierzytelności w pełni nie uzyskała ona $w$ toku postępowania upadłościowego. Konsekwencją umorzenia postępowania sądowego jest to, że postępowanie to mogłoby toczyć się na nowo - w szczególności, gdy powód nie zrzekł się roszczenia - gdyż umorzenie postępowania nie nastąpiło na skutek cofnięcia pozwu, ale na skutek uznania za zbędne jego kontynuowanie. Umorzenie postępowania ma bowiem charakter rozstrzygnięcia formalnego, zaś oddalenie powództwa przesądza merytorycznie o treści dochodzonego żądania. Orzeczenie o takiej treści korzysta z powagi rzeczy osądzonej i skutkuje tym, że w przypadku podjęcia kolejnej próby inicjacji postępowania $\mathrm{w}$ tym przedmiocie, sąd winien pozew odrzucić na podstawie art. $199 \S 2$ pkt 2 k.p.c. Niemniej jednak, mając uzyskany tytuł egzekucyjny $\mathrm{w}$ postępowaniu upadłościowym, strona nie powinna być zainteresowana $\mathrm{w}$ ponownym prowadzeniu postępowania bez względu na to, czy sąd umorzył poprzednie postępowanie sądowe, czy też oddalił powództwo.

Nie ulega wątpliwości również to, że w sytuacji, gdyby sąd, kierując się interesem prawnym strony - na co wskazywał SN - byłby przekonany co do tego, że winien wydać orzeczenie merytoryczne i oddalić powództwo, to powinien przed wydaniem wyroku podjąć wszelkie działania mające na celu rozpoznanie sprawy co do jej istoty, a zatem przeprowadzić postępowanie dowodowe w takim zakresie, w jakim jest ono konieczne. Wydanie zaś postanowienia o umorzeniu postępowania nie musi być poprzedzone takimi czynnościami procesowymi, a zatem - z punktu widzenia interesu sądu prowadzącego postępowanie - postanowienie o umorzeniu postępowania może zostać wydane już we wcześniejszej fazie procesu niż wyrok oddalający powództwo.

Rozważania wskazane powyżej nakazują zwrócić uwagę na to, co powinno być również przedmiotem analizy $\mathrm{SN}$, a w treści powołanej 
uchwały zostało całkowicie pominięte. Wyraźnie bowiem zasygnalizować należy, że sąd apelacyjny zwrócił się z zagadnieniem prawnym do $\mathrm{SN}$ w konkretnym stanie faktycznym, a mianowicie na etapie rozpoznawania apelacji od wyroku, gdy pozyskał informację o zatwierdzeniu listy wierzytelności. Z rekonstrukcji stanu faktycznego dokonanej przez SN nie wynika, aby postępowanie upadłościowe w stosunku do jednego z pozwanych (tj. pozwanej spółki) zostało zakończone. Udzielenie przez SN odpowiedzi nie powinno pomijać tej okoliczności. To bowiem pojęcie „czasu” ma tutaj istotne znaczenie dla postępowania sądowego - konkretnie moment, w którym usprawiedliwione byłoby przez sąd wydanie postanowienia o umorzeniu postępowania sądowego na skutek uzyskania przez stronę ochrony prawnej w postępowaniu upadłościowym.

Wpływ postępowania upadłościowego, które toczy się przed sędzią-komisarzem, na postępowania sądowe prowadzone przez sądy od początku obowiązywania przepisów prawa upadłościowego stanowiło istotne zagadnienie i wciąż brak jest wydajnej regulacji w tym zakresie $e^{4}$. Sądy, podejmując decyzje procesowe, $\mathrm{w}$ związku z faktem ogłoszenia upadłości pozwanego, wykazują różnorodną praktykę orzeczniczą. Ostatnia nowelizacja przepisów prawa $\mathrm{w}$ tym zakresie przyniosła pewne uporządkowanie i nakazuje sądowi (zgodnie z treścią art. $174 \S 1$ pkt 4 k.p.c.) zawiesić toczące się postępowanie sądowe, jeżeli postępowanie dotyczy masy upadłości i ogłoszono upadłość oraz nakazuje wówczas wezwać syndyka do udziału w sprawie (zgodnie z treścią art. 174 § 3 k.p.c.). Podjęcie zaś zawieszonego postępowania (stosownie do treści art. $180 § 1$ pkt 5 lit b k.p.c.) może mieć miejsce wyłącznie z chwilą ustalenia osoby pełniącej funkcję syndyka, w sytuacji, gdy ogłoszono upadłość strony ${ }^{5}$, z wyjątkiem jednak określonym w art. 145 ust. 1 p.u. ${ }^{6}$

W praktyce oznacza to, że po zawieszeniu postępowania $\mathrm{z}$ uwagi na ogłoszenie upadłości pozwanego taki stan rzeczy winien utrzymywać się aż do czasu rozstrzygnięcia tej kwestii w postępowaniu upadłościowym. Podjęcie postępowania może nastąpić bowiem w przypadku, gdy w postępowaniu upadłościowym wierzytelność ta, po wyczerpaniu trybu

4 Szerzej zob. P. Feliga, [w:] A. Hrycaj, A. Jakubecki, A. Witosz (red.), Prawo restrukturyzacyjne i upadłościowe, System Prawa Handlowego 6, Warszawa 2016, s. 860-868.

5 Szerzej zob. P. Zimmerman, Prawo upadłościowe. Prawo restrukturyzacyjne. Komentarz, Warszawa 2016, s. 291-292.

6 Ustawa z dnia 28 lutego 2003 r. - Prawo upadłościowe, tekst jednolity: Dz. U. z 2019 r. poz. 498 z późn. zm. (dalej: p.u.). 
określonego ustawą, nie zostanie umieszczona na liście wierzytelności. Sam więc fakt umieszczenia wierzytelności na liście wierzy telności winien skutkować podjęciem postępowania sądowego, niemniej jednak dopiero po wyczerpaniu trybu określonego ustawą, przez który należy rozumieć moment zatwierdzenia listy wierzytelności, a zatem również rozpoznania sprzeciwów od listy wierzytelności, jeżeli takie byłyby w toku postępowania upadłościowego składane (art. 256 i art. 260 k.p.c.) ${ }^{7}$.

Konkluzją analizy przepisów jest stanowisko, że zbędne jest prowadzenie dwóch postępowań, których efekt byłby tożsamy. W treści głosowanej uchwały SN dochodzi również do identycznego wniosku, wskazując, że "[...] Chodzi bowiem o to, aby w obrocie nie funkcjonowały dwa różne tytuły egzekucyjne opiewające na to samo świadczenie". Nie ulega również wątpliwości, że w interesie sądu jest uniknięcie konieczności prowadzenia postępowania sądowego, którego efekt byłby tożsamy z efektem, jaki wierzyciel osiągnąłby w postępowaniu upadłościowym.

Mając zatem na uwadze treść stanowiska zajętego przez SN w głosowanej uchwale należałoby uznać, że wyczerpanie trybu określonego ustawą - a zatem po zatwierdzeniu listy wierzytelności w postępowaniu upadłościowym - winno skutkować podjęciem zawieszonego postępowania i jednocześnie jego umorzeniem. Warunkiem jest oczywiście to, że zatwierdzoną listą wierzytelności objęta została wierzytelność dochodzona przez powoda w przedmiotowym procesie. Ubocznie zaś należy wskazać, że wierzytelności w postępowaniu upadłościowym mogą być objęte uzupełniającymi listami wierzytelności, które w zasadzie, z pewnymi ograniczeniami, mogą być sporządzane $w$ toku postępowania upadłościowego i są zatwierdzane przez sędziego-komisarza. Skutek ich zatwierdzenia dla wierzycieli i upadłego jest identyczny, jak w przypadku zatwierdzenia listy wierzytelności. Tym samym więc, jeżeli wierzyciel jeszcze nie zgłosił wierzytelności $\mathrm{w}$ toku postępowania upadłościowego na listę wierzytelności, nie oznacza to, że nie może tego uczynić i dokonać zgłoszenia wierzytelności później. Wówczas jego wierzytelność objęta byłaby uzupełniającą listą wierzytelności, która podlegałaby zatwierdzeniu na dalszym etapie postępowania. Zatem mylne może być przeświadczenie sądu, że zatwierdzenie listy wierzytelności, na której brak jest wierzytelności objętej aktualnie toczącym się postępowaniem sądowym, winno prowadzić

7 Zob. P. Zimmerman, Prawo upadłościowe..., s. 292; S. Gurgul, Prawo upadłościowe. Prawo restrukturyzacyjne. Komentarz, Warszawa 2016, s. 389. 
do podjęcia postępowania z udziałem syndyka i dalszego procedowania zgodnie z treścią art. $180 \S 1$ pkt 5 lit b k.p.c. w zw. z art. 145 ust. 1 p.u. skoro wierzytelność ta nie została zamieszczona na liście wierzytelności, która to lista wierzytelności została zatwierdzona ${ }^{8}$. Kontynuowanie bowiem postępowania $\mathrm{w}$ tak zaistniałym stanie faktycznym oznaczałoby, że sąd mógłby doprowadzić do „zdublowania” tytułów egzekucyjnych, co stałoby w sprzeczności ze stanowiskiem SN zawartym w treści glosowanej uchwały, gdyż sąd wydałby wyrok uwzględniający powództwo a jednocześnie wierzyciel dokonałby późniejszego zgłoszenia tej samej wierzytelności na uzupełniającą listę wierzytelności, która zostałaby zatwierdzona przez sędziego-komisarza.

Umorzenie postępowania sądowego, do czego zachęca $\mathrm{w}$ treści uchwały SN, dotyczy jedynie sytuacji, gdy wierzytelność, co do której toczy się postępowanie sądowe, została objęta zatwierdzoną listą wierzytelności, czy też uzupełniającą listą wierzytelności. Sąd Najwyższy w przytoczonej tezie wskazuje jednak kategorycznie, że „uzyskanie przez powoda po wszczęciu postępowania tytułu egzekucyjnego w postaci wyciągu z zatwierdzonej przez sędziego-komisarza listy wierzytelności skutkuje umorzeniem postępowania na podstawie art. 355 $\S 1$ k.p.c." W treści uzasadnienia pomija zaś fakt, że postępowanie upadłościowe w zaistniałym stanie faktycznym, który wymusił na sądzie apelacyjnym zwrócenie się z zagadnieniem prawnym, nie doszło do zakończenia postępowania upadłościowego. Istnieje tym samym potrzeba zdefiniowania charakteru prawnego wyciągu z zatwierdzonej przez sędziego-komisarza listy wierzytelności z uwagi na ważny moment powstania tytułu egzekucyjnego.

Wyciąg z zatwierdzonej listy wierzytelności wierzyciel może uzyskać na każdym etapie postępowania upadłościowego. Oczywiście mając na uwadze to, że doszło już do uprzedniego zatwierdzenia tej listy. Sam wyciąg z listy wierzytelności stanowi informację dla wierzyciela odnośnie do wysokości wierzytelności uznanej w postępowaniu upadłościowym i nie ma większego znaczenia prawnego.

Sąd Najwyższy w treści uchwały wskazuje zaś na wyciąg z zatwierdzonej listy wierzytelności, który ma być tytułem egzekucyjnym. W treści

8 Szerzej o wpływie postępowania upadłościowego na toczące się postępowanie sądowe zob. A. Jakubecki, F. Zedler, Prawo upadłościowe i naprawcze. Komentarz, Warszawa 2010, s. 333-357. 
glosowanej uchwały nie odnosi się natomiast w ogóle do tego, kiedy tytuł egzekucyjny w postępowaniu upadłościowym powstaje. Nie bez znaczenia jest więc pełna treść art. 264 ust. 1 p.u., który to przepis stanowi, iż dopiero po zakończeniu lub umorzeniu postępowania upadłościowego wyciąg z zatwierdzonej przez sędziego-komisarza listy wierzytelności (zawierający oznaczenie wierzytelności oraz sumy otrzymanej na jej poczet przez wierzyciela) jest tytułem egzekucyjnym przeciwko upadłemu ${ }^{9}$. Sam moment zatwierdzenia listy wierzytelności nie skutkuje tym, że tytuł egzekucyjny już powstaje ${ }^{10}$.

Powyższe rozważania $\mathrm{w}$ zestawieniu $\mathrm{z}$ tezą SN prowadzą więc do konkluzji, że moment, gdy wierzytelność powoda - co do którego toczy się postępowanie sądowe - została uznana na zatwierdzonej liście wierzytelności, nie może warunkować umorzenia postępowania sądowego. Sąd Najwyższy mówi bowiem o uzyskaniu przez wierzyciela tytułu egzekucyjnego w postępowaniu upadłościowym, a tym tytułem egzekucyjnym wierzyciel będzie mógł się legitymować dopiero po zakończeniu postępowania upadłościowego lub po jego umorzeniu ${ }^{11}$. Uchwała SN nie stanowi więc remedium dla sądu apelacyjnego w kontekście przywołanego stanu faktycznego. Z punktu widzenia zaś praktyki orzeczniczej sądów błędna interpretacja tezy SN - z uwagi na brak uzupełnienia jej treści o wyrażenie „po zakończeniu lub umorzeniu postępowania” - może prowadzić do wadliwej praktyki orzeczniczej. Literalna wykładnia jej treści stwarza bowiem wrażenie, że sąd jest uprawniony do umorzenia postępowania sądowego w sytuacji, gdy pozyska wiarygodną informację o tym, że wierzytelność, co do której prowadzi postępowanie sądowe, została uznana na zatwierdzonej liście wierzytelności, gdyż powód uzyskał już tytuł egzekucyjny. Sąd Najwyższy nie doprecyzował zaś, że tytuł egzekucyjny powód tak naprawdę uzyska dopiero po zakończeniu lub umorzeniu

9 Zob. A. Jakubecki, F. Zedler, Prawo upadłościowe i naprawcze..., s. 566-567; P. Janda, Prawo upadłościowe. Komentarz, Warszawa 2017, s. 679; R. Adamus, Prawo upadtościowe. Komentarz, Warszawa 2016, s. 697-698.

10 Szerzej na temat rozumienia pojęcia tytułu egzekucyjnego $\mathrm{w}$ postępowaniu upadłościowym w poprzednim stanie prawnym, tj. w okresie obowiązywania rozporządzenia Prezydenta Rzeczypospolitej z dnia 24 października 1934 r. - Prawo upadłościowe, Dz. U. z 1934 r. Nr 93, poz. 834 (objęte tekstem jednolitym: Dz. U. z 1991 r. Nr 118, poz. 512 z późn. zm.), F. Zedler, Prawo upadłościowe i układowe, Torun 1999, s. 212.

11 Szerzej na temat charakteru prawnego listy wierzytelności zob. A. Jakubecki, [w:] A. Hrycaj, A. Jakubecki, A. Witosz (red.), Prawo restrukturyzacyjne..., s. 1019-1024. 
postępowania upadłościowego. Na tym etapie postępowania odpada więc przesłanka „zbędności” dalszego prowadzenia postępowania, na którą się powoływano.

Powyższe trzeba rozważyć w kontekście zagadnienia, czy umorzenie postępowania sądowego nie mogłoby zaistnieć w sytuacji, gdyby tytułu egzekucyjnego $\mathrm{w}$ postaci wyciągu $\mathrm{z}$ zatwierdzonej listy wierzytelności wierzyciel jeszcze nie posiadał, gdyż postępowanie upadłościowe nie zostało zakończone lub umorzone. Postępowanie upadłościowe może bowiem zakończyć się wyłącznie dwojako: poprzez stwierdzenie jego zakończenia na skutek wykonania ostatecznego planu podziału zgodnie z treścią art. 368 ust. 1 p.u., albo poprzez jego umorzenie stosownie do treści art. 361 p.u. ${ }^{12}$ Tym samym $\mathrm{w}$ sytuacji, gdy w toku postępowania upadłościowego doszło do zatwierdzenia listy wierzytelności, to w zasadzie nie ma żadnego zagrożenia, że tytuł egzekucyjny w toku tego postępowania nie powstanie.

Odnotować wypada, że postanowienie o zatwierdzeniu listy wierzytelności nie jest postanowieniem kończącym postępowanie $w$ sprawie w rozumieniu treści art. $359 \S 1$ k.p.c. w zw. z art. 229 p.u. Oznacza to, że wskutek zmiany okoliczności sprawy postanowienie to może być przez sędziego-komisarza uchylone. W efekcie skutkowałoby to tym, że po zakończeniu lub umorzeniu postępowania upadłościowego nie powstałby tytuł egzekucyjny, gdyby sędzia-komisarz uchylił postanowienie o zatwierdzeniu listy wierzytelności i tej listy nie zatwierdził już do końca trwania postępowania upadłościowego. Pochopne umorzenie postępowania sądowego po zatwierdzeniu listy wierzytelności, a następnie uchylenie przez sędziego-komisarza postanowienia o zatwierdzeniu listy wierzytelności, pozbawiłoby wierzyciela jakiegokolwiek tytuł egzekucyjnego zarówno w postępowaniu upadłościowym, jak również w postępowaniu sądowym.

Tytuł egzekucyjny dla wierzyciela ma również przedstawiać realną „wartość”. Z jego treści ma wynikać bowiem to, w jakiej wysokości może on domagać się zaspokojenia roszczeń od dłużnika. Ustawodawca racjonalnie uznał więc, że w postępowaniu upadłościowym tytuł egzekucyjny powstaje dopiero po jego zakończeniu lub umorzeniu, gdyż wówczas tak naprawdę wiadomo, jaką „wartość” ten tytuł przedstawia dla

12 Szerzej na temat zakończenia i umorzenia postępowania upadłościowego zob. R. Adamus, Prawo upadtościowe..., s. 835-836, 841-844. 
wierzyciela. Celem postępowania upadłościowego jest przede wszystkim zaspokojenie roszczeń wierzycieli w jak najwyższym stopniu. Postępowania upadłościowego nie inicjuje się wyłącznie w celu kreacji tytułów egzekucyjnych dla wierzycieli, którzy dochodzić mieliby swoich roszczeń po jego zakończeniu. W postępowaniu upadłościowym może więc dojść do całkowitego lub częściowego zaspokojenia roszczeń wierzycieli. Nie bez przyczyny więc w treści art. 264 ust. 1 p.u. wskazano, że wyciąg z zatwierdzonej listy wierzytelności ma zawierać oznaczenie wierzytelności oraz sumy otrzymanej na jej poczet przez wierzyciela. W postępowaniu egzekucyjnym po zakończeniu postępowania upadłościowego wierzyciel mógłby dochodzić swoich roszczeń tylko w takim zakresie, w jakim wierzytelność ta nie została zaspokojona $\mathrm{w}$ toku postępowania upadłościowego. Tytuł ten będzie bowiem skuteczny wyłącznie w takim zakresie. Zatem umorzenie postępowania sądowego już w sytuacji zatwierdzenia listy wierzytelności nie może być uzasadnione stanowiskiem, że wierzyciel ma interes prawny w dochodzeniu całości roszczenia - a wyłącznie zbędne jest dalsze prowadzenie postępowania. W chwili orzekania w tym przedmiocie trudno jest bowiem przesądzić, czy wierzytelność w toku postępowania nie zostanie choćby w części zaspokojona. Moment podejmowania decyzji skutkować musiałby odmienną oceną stanu faktycznego. Częściowe zaspokojenie roszczeń wierzyciela w toku postępowania upadłościowego po zatwierdzeniu listy wierzytelności oznaczałoby, że wierzyciel nie miałby interesu prawnego $\mathrm{w}$ dochodzeniu roszczenia $\mathrm{w}$ tym zakresie, a zatem nie trudno znaleźć uzasadnienie dla stanowiska o konieczności częściowego oddalenia powództwa - wbrew stanowisku, co do umorzenia postępowania. Jest to więc kolejny argument uzasadniający tezę, że moment podjęcia decyzji o umorzeniu postępowania sądowego ma dość istotne znaczenie. 


\section{Podsumowanie}

Konkludując i mając na uwadze powołane argumenty należy uznać, że stanowisko SN, co do konieczności umorzenia postępowania sądowego $\mathrm{w}$ momencie uzyskania przez wierzyciela tytułu egzekucyjnego $\mathrm{w}$ postaci wyciągu z zatwierdzonej listy wierzytelności, o ile może zostać uznane za trafne, o tyle jest jednak niepełne. Brak precyzyjnego dookreślenia tezy SN - pozbawionej informacji, że tytuł egzekucyjny powstaje dopiero po zakończeniu postępowania upadłościowego lub jego umorzeniu, a zatem dopiero wówczas mogłoby nastąpić umorzenie postępowania sądowego - może prowadzić do wadliwej praktyki orzeczniczej sądów ${ }^{13}$. Sygnał dla sądu, że może umorzyć postępowanie sądowe w sytuacji zatwierdzenia listy wierzytelności, może być na tyle silny, że sądy będą podejmowały decyzje o umorzeniu prowadzonych postępowań bez oczekiwania na rezultat $\mathrm{w}$ postaci finalizacji postępowania upadłościowego. O ile takie rozstrzygnięcia sądów byłyby jak najbardziej pożądane z punktu widzenia ilości prowadzonych postępowań sądowych oraz konieczności unikania utrzymywania stanu rzeczy zawieszonych postępowań sądowych, to jednak wypaczałyby znaczenie, cel i rozumienie podstawowych instytucji prawnych, w szczególności prawa upadłościowego.

W aktualnym stanie prawnym niestety brak jest podstaw do uznania, że sąd po zatwierdzeniu listy wierzytelności mógłby podjąć decyzję o umorzeniu postępowania sądowego, które dotyczy tej samej wierzytelności. Takie rozwiązanie jest niewątpliwie pożądane i „życzeniowe”, niemniej jednak absolutnie nie znajduje uzasadnienia prawnego $\mathrm{w}$ obowiązujących przepisach prawa. Rozważyć należałoby $\mathrm{w}$ tym zakresie zmianę przepisów prawa, która skutkowałaby uniknięciem "fikcyjnego" prowadzenia postępowań sądowych w momencie ogłoszenia już upadłości pozwanego.

13 Stanisław Gurgul stoi na stanowisku, że sporządzenie listy wierzytelności i jej zatwierdzenie $\mathrm{w}$ postępowaniu upadłościowym nie może być traktowane jako osądzenie sprawy w znaczeniu wynikającym z przepisów Kodeksu postępowania cywilnego. Tym samym orzeczenie uzyskiwane $\mathrm{w}$ postępowaniu upadłościowym nie korzysta $\mathrm{z}$ res iudicata, a w konsekwencji uznać należałoby, że brak jest podstaw do oddalenia powództwa w postępowaniu sądowym, zob. tenże, Prawo upadtościowe..., s. 614. Andrzej Jakubecki zajął stanowisko, że odmowa uznania wierzytelności na liście wierzytelności nie korzysta z powagi rzeczy osądzonej, zob. tenże, [w:] A. Hrycaj, A. Jakubecki, A. Witosz (red.), Prawo restrukturyzacyjne..., s. 1023. 
Zupełnie odmiennym zagadnieniem jest wątpliwa kwestia obciążenia kosztami postępowania pozwanego w sytuacji, gdyby sąd zdecydował się na umorzenie postępowania sądowego. Sąd Najwyższy w treści glosowanej uchwały nie odniósł się do tego zagadnienia w żaden sposób. Uznać należy, że pozwany, co do zasady, dał podstawę do wytoczenia powództwa powodowi, niemniej jednak faktycznie powód uzyska tytuł egzekucyjny w postępowaniu upadłościowym, gdzie z kolei nie ma obowiązku ponoszenia $\mathrm{z}$ tego tytułu żadnych kosztów postępowania. Trudno więc jest bronić stanowiska, że kosztami postępowania sądowego winien być w całości obciążony pozwany.

Co do zasady, glosowana uchwała SN wskazuje właściwy kierunek, ale z uwagi na brak właściwych przepisów prawa, nie może przesądzać o unikaniu prowadzenia podwójnych postępowań dotyczących tej samej wierzy telności, tj. postępowania upadłościowego i postępowania sądowego. Należy zatem usilnie zabiegać o zmiany legislacyjne w tym zakresie tak, aby prowadzenie postępowań sądowych było efektywne i minimalizowało konieczność podejmowania działań w dwóch różnych postępowaniach w sytuacji, gdy efekt oraz cel byłby taki sam - uzyskanie tytułu egzekucyjnego.

Słowa kluczowe: lista wierzytelności, umorzenie postępowania, tytuł egzekucyjny, postępowanie sądowe, postępowanie upadłościowe

\section{Bibliografia}

\section{Źródła}

\section{Akty prawne}

Rozporządzenie Prezydenta Rzeczypospolitej z dnia 24 października $1934 \mathrm{r}$. - Prawo upadłościowe, Dz. U. z 1934 r. Nr 93, poz. 834; tekst jednolity: Dz. U. z 1991 r. Nr 118, poz. 512 z późn. zm.

Ustawa z dnia 17 listopada 1964 r. - Kodeks postępowania cywilnego, tekst jednolity: Dz. U. z 2019 r. poz. 1460 z późn. zm.

Ustawa z dnia 28 lutego 2003 r. - Prawo upadłościowe, tekst jednolity: Dz. U. z 2019 r. poz. 498 z późn. zm. 


\section{Orzecznictwo}

Uchwała Sądu Najwyższego z dnia 18 stycznia 2019 r., III CZP 55/18, Baza Orzeczeń - Sąd Najwyższy, http:/ / www.sn.pl/sites/orzecznictwo/orzeczenia3/ iii\%20czp\%2055-18.pdf [dostęp: 23.04.2019 r.].

Postanowienie Sądu Najwyższego z dnia 5 grudnia 1996 r., I PKN 34/96, OSNP 1997, nr 13, poz. 237.

Postanowienie Sądu Najwyższego z dnia 23 lutego 2001 r., II CKN 393/00, OSNC 2001, nr 11, poz. 162.

Postanowienie Sądu Najwyższego z dnia 2 lutego 2006 r., II CK 391/05, niepubl.

Postanowienie Sądu Najwyższego z dnia 3 kwietnia 2008 r., II CSK 561/07, OSNC-ZD 2009, nr 2, poz. 38.

\section{Literatura}

Adamus R., Prawo upadłościowe. Komentarz, Warszawa 2016.

Feliga P., [w:] A. Hrycaj, A. Jakubecki, A. Witosz (red.), Prawo restrukturyzacyjne i upadłościowe, System Prawa Handlowego 6, Warszawa 2016.

GurgulS., Prawo upadłościowe. Prawo restrukturyzacyjne. Komentarz, Warszawa 2016. Hrycaj A., A. Jakubecki, A. Witosz (red.), Prawo restrukturyzacyjne i upadłościowe, System Prawa Handlowego 6, Warszawa 2016.

Jakubecki A., [w:] A. Hrycaj, A. Jakubecki, A. Witosz (red.), Prawo restrukturyzacyjne i upadłościowe, System Prawa Handlowego 6, Warszawa 2016.

Jakubecki A., F. Zedler, Prawo upadłościowe i naprawcze. Komentarz, Warszawa 2010. Janda P., Prawo upadłościowe. Komentarz, Warszawa 2017.

Zedler F., Prawo upadłościowe i układowe, Torun 1999.

Zimmerman P., Prawo upadłościowe. Prawo restrukturyzacyjne. Komentarz, Warszawa 2016.

\section{LIST OF CLAIMS AND DISCONTINUATION OF COURT PROCEEDINGS COMMENTARY TO THE RESOLUTION OF THE SUPREME COURT JUDGMENT OF 18 JANUARY 2019, CASE III CZP 55/18}

\section{Sum mary}

In bankruptcy proceedings, the creditor obtains an enforcement order in the form of an excerpt from an approved list of claims. It may be the basis for conducting enforcement, but only after the bankruptcy proceedings have ended. However, the creditor (plaintiff) may initiate court proceedings earlier, which may lead to the bankruptcy of the debtor (defendant). Concurrent bankruptcy proceedings and court proceedings, the purpose of which is to obtain the same writ of execution, has no factual justification. It seems necessary to find a legal solution that 
would inhibit duplication of two proceedings, the effect of which is partially identical. The author, based on the content of the Supreme Court's ruling, points to an existing legal problem and the lack of an effective legal solution. It explains why the Supreme Court's thesis is neither a remedy for the problems of the courts nor a sufficient hint as to further procedural steps in such a state of affairs.

Key words: list of claims, discontinuance of proceedings, enforcement order, court proceedings, bankruptcy proceedings

\section{ПЕРЕЧЕНЬ ДОЛГОВЫХ ТРЕБОВАНИЙ И ПРЕКРАЩЕНИЕ СУДЕБНОГО РАЗБИРАТЕЛЬСТВА NGLOSA ПО РЕШЕНИЮ ВЕРХОВНОГО СУДА ОТ 18 ЯНВАРЯ 2019 ГОДА, НОМЕР ДЕЛА ІІІ СZР 55/18 \\ Резюме}

В процессе банкротства кредитор получает исполнительный лист в виде выписки из утвержденного перечня долговых требований. Он может быть основанием для проведения принудительного взыскания, но только после окончания процедуры банкротства. Однако кредитор (истец) может ранее инициировать судебное разбирательство, в ходе которого может быть объявлено банкротство должника (ответчика). Ведение одновременно процедуры банкротства и судебного разбирательства, целью которого является получение того же исполнительного листа, не имеет фактического обоснования. Представляется необходимым найти правовое решение, которое препятствовало бы „дублированию” ведения двух разбирательств, результат которых частично идентичен. Автор, основываясь на содержании постановления Верховного суда, указывает на существующую юридическую проблему и отсутствие эффективного юридического решения. Он объясняет, почему тезис Верховного суда также не является средством решения проблем судов и достаточным указанием на дальнейшие процедурные шаги при существующем положении дел.

Ключевые слова: перечень требований, прекращение производства, исполнительный лист, судебное разбирательство, процедура банкротства 
